\title{
Izvješće o napretku Hrvatske 2008: Poglavlje o oporezivanju
}

\section{dr. sc. Katarina Ott}

Europska komisija je 5. studenog objavila Izvješće o napretku Hrvatske 2008. koje se odnosi na razdoblje od 1 . studenog 2007. do 3. studenog $2008 .{ }^{1}$ Izvješće ocjenjuje hrvatske napore u primjeni pravne stečevine, odnosno sustava prava i obaveza za sve članice EU. Napredak se mjeri na temelju donesenih odluka, prihvaćenih zakona i primijenjenih mjera. Iako je Vlada predstavila Izvješće građanima kao vrlo povoljno i obećavajuće za brzi ulazak u EU, «pod uvjetom da sami obavimo svoj dio posla», imalo upućeni u poreze teško mogu biti optimistični.

Pravna stečevina je skup načela koja treba inkorporirati u zakonodavstvo zemalja članica. S vremenom se razvijala i danas se sastoji od trideset i tri poglavlja o kojima zemlje kandidatkinje pregovaraju s EU, a oporezivanje je samo jedno od njih. Pravna stečevina koja se odnosi na oporezivanje, odnosno poglavlje 16, obuhvaća: indirektno oporezivanje; direktno oporezivanje; administrativnu suradnju i međusobnu pomoć, te operativnu sposobnost i kompjutorizaciju.

Nažalost, ali ne i iznenađujuće za upućene u to područje, Izvješće o oporezivanju je katastrofalno. Utvrđeno je sljedeće:

- Ne može se izvijestiti o napretku u području indirektnog oporezivanja.

- Nema napretka u području direktnog oporezivanja.

- Ne može se izvijestiti o napretku u administrativnoj suradnji i međusobnoj pomoći.

- Postoji izvjestan napredak u operativnoj sposobnosti i kompjutorizaciji.

Zaključak o oporezivanju je sljedeći: «Vrlo je ograničen napredak u tom poglavlju. Nije učinjen napredak u usklađivanju zakona. Iako je ukupna struktura poreznih zakona slična pravnoj stečevini, valja poduzeti znatne napore na svim područjima. Hrvatska se složila s Komisijom o rješenjima za ukidanje diskriminacijskog oporezivanja cigareta. Potrebni su značajni daljnji napori za jačanje administrativne sposobnosti, uključujući napore koji se tiču povezanosti informacijske tehnologije.»

Ovo izvješće možda i ne bi bilo toliko tragično da je to prvi put da Komisija ocjenjuje napredak poglavlja oporezivanja na takav način. Međutim, sva prethodna izvješća Komisije govorila su isto, više-manje s istim riječima «vrlo slab napredak» (2005), «ograničen napredak» (2006) i «vrlo ograničen napredak» (2007). ${ }^{2}$ Osim sporog napretka, ključni problemi koji se ponavljaju iz godine u godinu tiču se administrativne sposobnosti i povezanosti informacijske tehnologije.

\footnotetext{
${ }^{1}$ Izvješće je na engleskom jeziku dostupno na: http://ec.europa.eu/enlargement/pdf/press corner/keydocuments/reports nov 2008/croatia progress report en.pdf.

2 Prethodna izvješća na engleskom jeziku dostupna su na:

http://ec.europa.eu/enlargement/archives/pdf/key documents/2005/package/sec 1424 final progress report
} 
Zadnji dostupni podaci Misije Hrvatske pri EU iz kolovoza 2008. pokazuju da pregovori o poglavlju oporezivanja zaostaju za drugim poglavljima. To znači da se 21 poglavlje nalazi u naprednijim fazama, dok pregovori o samo 10 poglavlja zaostaju za poglavljem oporezivanja. ${ }^{3}$ Budući da se poglavlje oporezivanja ne drži posebno teškim, zaostajanje u pregovorima o tom poglavlju ukazuje na slabosti hrvatske porezne administracije.

Očito je da Porezna uprava mora učiniti značajno veće napore ne samo u ubrzavanju već i u produbljivanju potrebnih reformi. Bez obzira na zahtjevne, ali ipak prije svega tehničke zahtjeve EU, značajni se napori moraju uložiti u izradu konzistentnih i uspješnih strategija i reformi, te njihovoj primjeni. Također se moraju smanjiti jaki politički, odnosno lobistički utjecaji, inzistirati na stručnim umjesto političkim postavljenjima u poreznoj administraciji, na transparentnosti njenog rada i boljem pristupu pouzdanijim informacijama i podacima. Samo profesionalna, kompetentna i odlučna porezna administracija može se upustiti u kvalitetne analize i ocjene tekućih potreba i inzistirati na primjeni, provedbi i koordinaciji reformskih mjera.

U ovom se tekstu neće govoriti o konkretnim mjerama koje je potrebno poduzeti da bi se zadovoljili zahtjevi poglavlja oporezivanja; zainteresirani čitatelji ih mogu naći u različitim brojevima Newslettera Instituta za javne financije. ${ }^{4}$ Naglasit će se samo neki od ključnih problema koji negativno utječu na administrativnu sposobnost Porezne uprave. To su neadekvatan sustav plaćanja i nagrađivanja službenika, nedostatak konzistentne obuke službenika, te nedovoljne mogućnosti i manjak poticaja službenicima da unapređuju poslovanje Porezne uprave. Ti bi se problemi mogli riješiti izdvajanjem Porezne uprave iz općeg sustava javne uprave, utvrđivanjem statusa sličnog Narodnoj banci te promjenom propisa koji reguliraju zapošljavanje i otpuštanje, te plaće i nagrade u Poreznoj upravi.

Bez ispunjenja spomenutih preporuka, Porezna uprava bi se - čak i ako nekako uđemo u EU mogla tamo naći slabo pripremljena za postizanje osnovnih ciljeva porezne pravne stečevine, kao što su kontrola prekograničnog poslovanja poduzeća i borba protiv utaje poreza.

Moramo istovremeno biti svjesni i činjenice da su okolnosti danas posve drugačije nego u vrijeme kad se dvanaest novih članica priključivalo Uniji. U međuvremenu je EU postala svjesna problema preostalih u novim članicama i prepreka koje ti problemi postavljaju zadovoljavajućem funkcioniranju zajedničkog tržišta. Hrvatska Uniji pristupa individualno, pa ju je mnogo lakše strogo kontrolirati nego da pristupa u skupini zemalja. U usporedbi sa skupinom zemalja Srednje i istočne Europe, ili velikih država poput Poljske, Hrvatska kao mala zemlja nije posebno atraktivan zgoditak za zajedničko tržište. Konačno, stavovi, raspoloženje, pa i institucionalne okolnosti u EU, što se tiče daljnjih proširenja, danas su znatno nepovoljniji nego pri prethodnim proširenjima.

Vlada, Porezna uprava i Ministarstvo vanjskih poslova i europskih integracija moraju biti svjesni tih okolnosti i moraju iskreno i objektivno izvještavati građane o temama, problemima, razvoju i stanju pregovora. Umjesto toga, Porezna uprava na svojoj web stranici porazne ocjene poglavlja oporezivanja, pa ni samo Izvješće ni ne spominje. Web stranica Ministarstva vanjskih poslova i europskih integracija nudi začuđujuće oskudne informacije. Zadnji upisi na engleskom dijelu stranice posvećenom europskim integracijama su iz travnja! Među novostima i objavama za medije općeg dijela web stranice tog Ministarstva, Izvješće se uopće ne spominje! Možda nedostatak ključnih informacija nije dio neke zavjere kojom se građanima uskraćuju informacije, već samo još jedan dokaz potrebe jačanja administrativne sposobnosti $i$ to ne samo Porezne uprave.

\footnotetext{
hr en.pdf; http://ec.europa.eu/enlargement/pdf/key documents/2006/nov/hr sec 1385 en.pdf i

http://ec.europa.eu/enlargement/pdf/key_documents/2007/nov/croatia_progress_reports_en.pdf

3 Pregled stanja procesa pregovora dostupan je na: http://www.eu-pregovori.hr/files/PREGLED STANJA PROCESA PREGOVORA-2008-08-26-M1.pdf.

${ }^{4}$ Newsletteri su dostupni na http://www.ijf.hr/index.php?ime $=72$.
} 